\title{
Proceeding Paper \\ Numerical Simulation of Lead-Free Sn-Based Perovskite Solar Cell by Using SCAPS-1D ${ }^{\dagger}$
}

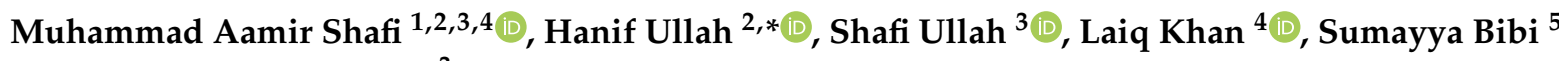 \\ and Bernabe Mari Soucase ${ }^{3}$
}

1 Department of Electrical Engineering, COMSATS University Islamabad, Abbottabad 22060, Pakistan; aamirshafi@ymail.com

2 Department of Electrical Engineering, Federal Urdu University, Islamabad 44000, Pakistan

3 Instituto de Diseño y Fabricación (IDF), Universitat Politécnica de València (UPV), 46022 Valencia, Spain; shafi399@yahoo.com (S.U.); bmari@fis.upv.es (B.M.S.)

4 Department of Electrical Engineering, COMSATS University Islamabad, Islamabad 45550, Pakistan; laiqkhan@comsats.edu.pk

5 Department of Electrical Engineering, Bahauddin Zakariya University, Multan 60800, Pakistan; sumiyyabibi@bzu.edu.pk

* Correspondence: hanifuet@yahoo.com; Tel.: +92-345-953-2660

+ Presented at the 1st International Conference on Energy, Power and Environment, Gujrat, Pakistan, 11-12 November 2021.

Citation: Shafi, M.A.; Ullah, H.;

Ullah, S.; Khan, L.; Bibi, S.; Soucase, B.M. Numerical Simulation of Lead-Free Sn-Based Perovskite Solar Cell by Using SCAPS-1D. Eng. Proc. 2021, 12, 92. https://doi.org/ 10.3390/engproc2021012092

Academic Editor: Shahid Iqbal

Published: 27 January 2022

Publisher's Note: MDPI stays neutral with regard to jurisdictional claims in published maps and institutional affiliations.

Copyright: (C) 2022 by the authors. Licensee MDPI, Basel, Switzerland. This article is an open access article distributed under the terms and conditions of the Creative Commons Attribution (CC BY) license (https:// creativecommons.org/licenses/by/ $4.0 /)$.

\begin{abstract}
Recent developments based on lead $(\mathrm{Pb})$ halide perovskites have inspired extensive research into low-cost solar cells in attempt to overcome the primary issues such as stability and toxicity that occur in this area. Solar cell simulation of lead-free perovskite $\left(\mathrm{CH}_{3} \mathrm{NH}_{3} \mathrm{SnBr}_{3}\right)$ as an absorber-based solar cell was performed using SCAPS-1D simulation tool in this work. An impact of absorber layer thickness and working temperature on photovoltaic characteristics of $\mathrm{CH}_{3} \mathrm{NH}_{3} \mathrm{SnBr}_{3}$-based perovskite solar cells was investigated using numerical modeling techniques. The thickness was varied from $1.0 \mu \mathrm{m}$ to $3.0 \mu \mathrm{m}$, and working temperature was varied from $290 \mathrm{~K}$ to $330 \mathrm{~K}$, and their effect was examined on the photovoltaic parameters of proposed "Back Contact $/ \mathrm{CH}_{3} \mathrm{NH}_{3} \mathrm{SnBr}_{3} / \mathrm{CdS} / \mathrm{ZnO} /$ Front Contact" solar cell. The improvement in the efficiency of solar cell by optimization of $\mathrm{CH}_{3} \mathrm{NH}_{3} \mathrm{SnBr}_{3}$ absorber layer thickness and working temperature was observed.
\end{abstract}

Keywords: perovskite; absorber layer; efficiency; simulation; SCAPS-1D

\section{Introduction}

Perovskite solar cells are becoming more important, because they have quickly increased in efficiency from $3.90 \%$ to $22.70 \%$ in recent years [1-5]. PCE has increased dramatically due to superior optoelectronic characteristics such as a high absorption coefficient $\left(10^{5} \mathrm{~cm}^{-1}\right)$, low exciton binding energy $(20 \mathrm{meV})$, and a comparatively long carrier diffusion lifetime $(>1 \mathrm{~m})$. Furthermore, perovskite structural engineering from the basic methyl ammonium lead iodide $\left(\mathrm{CH}_{3} \mathrm{NH}_{3} \mathrm{PbI}_{3}\right)$ perovskite to novel mixed-cation and mixed-anion halide perovskite materials yields excellent efficiency [6-9]. Despite the tremendous progress, the total PCE of perovskite-based solar cells is still far from the Shockley-Queisser limit (SQL), which is 30.50 percent PCE for a single methyl ammonium lead iodide $\left(\mathrm{MAPbI}_{3}\right)$-based junction cell. Again, it has been claimed that a NiO-based inverted structure device can outperform a planner structure in terms of stability [10].

Despite this, there are still a number of issues that prevent the manufacture of Snbased PVSC with bromine (Br) as the cation. This paper suggests a novel absorber layer using perovskite- $\mathrm{CH}_{3} \mathrm{NH}_{3} \mathrm{SnBr}_{3}$ to build a non-toxic, highly efficient, and stable PVSC. We simulated a lead-free perovskite solar cell, using tin $(\mathrm{Sn})$ instead of lead $(\mathrm{Pb})$, as lead is a toxic material. We used SCAPS-1D simulator to validate the lead-free, Sn-based perovskite 
solar cell under dark and illuminated conditions. After that, the effects of absorber layer thickness and working temperature were investigated.

\section{Numerical Modeling and Simulation}

SCAPS was used to model and simulate the thin film solar cell. The basic idea behind this software is to use numerical differentiation and Gummel type iteration approach in order to resolve the continuous differential equations as well as Poisson's differential equation [11,12]. The purposed solar cell structure is "Back Contact/Perovskite/CdS/ZnO/Front Contact/Glass" here, where $\mathrm{CH}_{3} \mathrm{NH}_{3} \mathrm{SnBr}_{3}$ Perovskites material is being used as an absorber layer, $\mathrm{CdS}$ as a buffer layer, and $\mathrm{ZnO}$ as a window layer. For the back and front contact, we used the SCAPS data by default. The value of absorption coefficient of each layer is taken from the SCAPS default value. All simulation settings for each layer in the structure are obtained from the literature [13-15].

\section{Results and Discussion}

Using SCAPS-1D simulator, simulation was carried out at $300 \mathrm{~K}$ working temperature under AM 1.5 G 1 sun illumination [16-18]. The effect of defects is not considered for this simulation and has been left for the researcher to check its effect. Energy band diagram taken from SCAPS-1D software is of proposed solar model "Back Contact $/ \mathrm{CH}_{3} \mathrm{NH}_{3} \mathrm{SnBr}_{3} / \mathrm{CdS} / \mathrm{ZnO} /$ Front Contact" shown in Figure 1a. The energy bad diagram is used to discuss the optical properties of solar cell [19]. The band gap of CdS buffer layer is adjusted with $\mathrm{CH}_{3} \mathrm{NH}_{3} \mathrm{SnBr}_{3}$ absorber and $\mathrm{ZnO}$ window layers. More or equal to $1.30 \mathrm{eV}$ is the band gap level for incident light photons that is best for absorbing the majority of the light for maximum power conversion efficiency [20]. Here, in our case, the band gap of $\mathrm{CH}_{3} \mathrm{NH}_{3} \mathrm{SnBr}_{3}$ absorber layer is $1.30 \mathrm{eV}$. Similarly, the band gaps of CdS and $\mathrm{ZnO}$ are 2.2 and $3.3 \mathrm{eV}$ of these buffer and window layers, respectively.

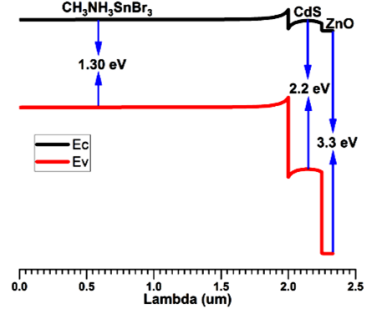

(a)

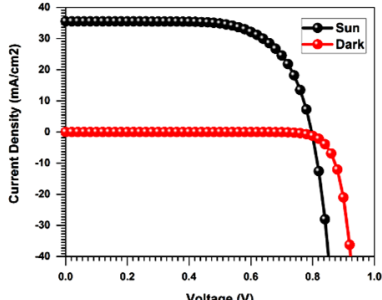

(b)

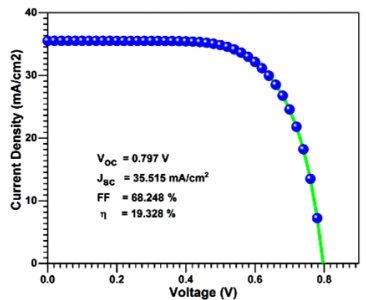

(c)

Figure 1. Proposed Solar Cell's (a) Energy Band Diagram (b) J-V Curve under dark and sun (c) Initial J-V curve.

A photovoltaic cell's principal function is to convert light energy into electrical energy. A PV cell is a large flat diode that creates an exponential J-V curve in dark. A PV device produces a very low current value due to minority carriers in the dark. The solar cell starts to work when it is exposed to light, causing generation of charge carriers. Figure $1 \mathrm{~b}$ is representing the J-V curve of our proposed solar cell under dark and suns both conditions. The simulation was run without any variation; an initial $\mathrm{J}-\mathrm{V}$ curve that we plotted is represented in Figure 1c. We obtained an open circuit voltage $\left(V_{o c}\right)$ of $0.797 \mathrm{~V}$, and a short circuit current density $\left(J_{s c}\right)$ of $35.5 \mathrm{~mA} / \mathrm{cm}^{2}$ was recorded. In the case of fill factor and efficiency, they were $68.24 \%$ and $19.34 \%$, respectively. To observe the effect of thickness of perovskite absorber layer on the performance of the solar cell, the thickness was varied from $1.0 \mu \mathrm{m}$ to $3.0 \mu \mathrm{m}$. By increasing the thickness from $1.0 \mu \mathrm{m}$ to $3.0 \mu \mathrm{m}$, we observe that the $\mathrm{J}-\mathrm{V}$ characteristics curve moves away from the origin as represented in Figure 2a. The effect of thickness on the $\mathrm{P}-\mathrm{V}$ characteristics curves is also clear in Figure $2 \mathrm{~b}$. From this figure, we note that, by increasing the thickness of the absorber layer, the power density of a cell improves, because by increasing a thickness of absorber layer, the chance of photons capturing increases; hence, more sun power is converted into electrical power density. 
At $1.0 \mu \mathrm{m}$ thickness of $\mathrm{CH}_{3} \mathrm{NH}_{3} \mathrm{SnBr}_{3}, V_{o c}$ was $0.79 \mathrm{~V}$, and $J_{\mathcal{~}}$ was $35.2 \mathrm{~mA} / \mathrm{cm}^{2}$, and the fill factor of $57.45 \%$ and eta was recorded up to $16.17 \%$, but when the thickness was increased from $1.0 \mu \mathrm{m}$ to $1.5 \mu \mathrm{m}$, the characteristics parameters were changed to $0.795 \mathrm{~V}$, $35.43 \mathrm{~mA} / \mathrm{cm}^{2}, 63.79 \%$, and $17.98 \%$, respectively. Here, we observe that there is a major improvement in the efficiency, increasing by approximately $2 \%$ by increasing the thickness from 1.0 to $1.5 \mu \mathrm{m}$.

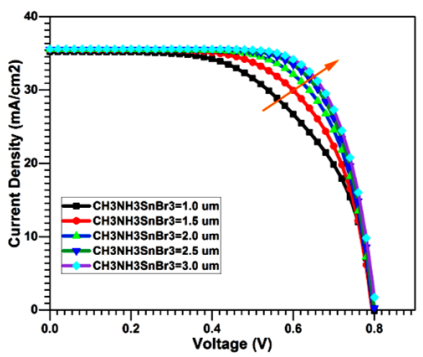

(a)

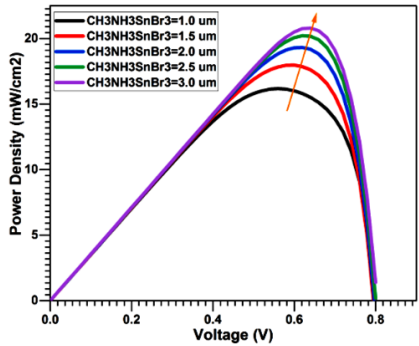

(b)

Figure 2. (a) J-V characteristics curve (b) P-V characteristic curve affected by absorber layer thickness.

Working temperature has a significant impact on photovoltaic device performance. The photovoltaic panels were set up outside in the open. The performance of photovoltaic cells was reduced as a result of the increased heating in a solar cell due to sunshine. The temperature of solar cell panels was over $300 \mathrm{~K}$. An impact of the proposed cell's operating temperature is also studied. We choose a temperature range of 290 to $330 \mathrm{~K}$ for our study. Figure $3 a, b$ illustrate the simulation results of $\mathrm{J}-\mathrm{V}$ and $\mathrm{P}-\mathrm{V}$ characteristics curves affected by the working temperature.

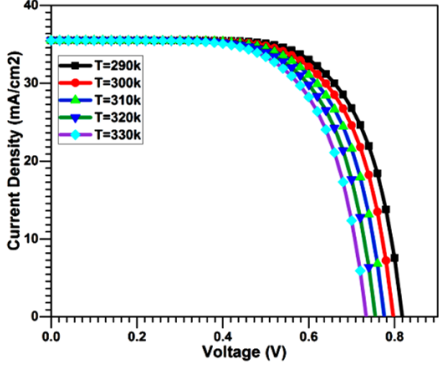

(a)

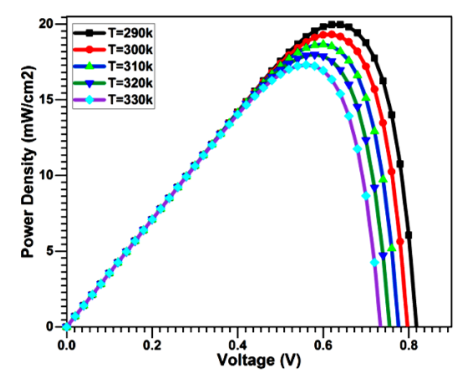

(b)

Figure 3. (a) $\mathrm{J}-\mathrm{V}$ and (b) $\mathrm{P}-\mathrm{V}$ curves affected by the working temperature.

$V_{o c}$ is directly influenced by temperature, which has an impact on the overall performance of solar cells. As temperature rises, efficiency of solar cells decreases. Higher temperatures affect the material carrier concentration, band gaps, and electron and hole motilities, causing low efficiency [21].

Saturation current in reverse $J_{0}$ is temperature dependent, and as a result, $V_{o c}$ drops as the temperature rises. As the temperature rises, the reverse saturation current decreases, and this drop in current is the primary source of the fall in $V_{o c}$, as seen in Equation (1) [22,23]. The greater working temperature provides more energy to electrons. Due to the increased temperature, these electrons are more likely to recombine with the holes before reaching the depletion area. The PCE of a cell diminishes as temperature rises; similarly, FF and $V_{o c}$ both drop as the temperature rises; hence, the $J_{S C}$ also decreases, as shown in Figure $4 \mathrm{a}, \mathrm{b}$.

$$
J_{e}(V)=J_{0}\left[\exp \left(\frac{q V_{o c}}{k_{B} T}\right)-1\right]
$$


Here, in Table 1, we compare the results of the initial cell simulated with the optimized thickness and temperature operated purposed perovskite based solar cell.

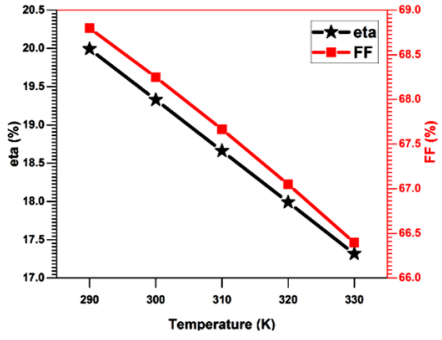

(a)

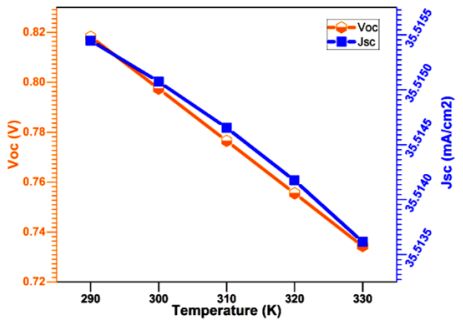

(b)

Figure 4. Characteristics Parameters affected by the working temperature (a) Eta and FF vs. Temperature (b) $V_{o c}$ and $J_{S c}$ vs. Temperature.

Table 1. Comparison of characteristics parameters of purposed device at first and last optimized conations.

\begin{tabular}{ccccc}
\hline \multirow{2}{*}{ Simulation } & $\boldsymbol{V}_{\boldsymbol{o c} \boldsymbol{\prime}}$ & $\boldsymbol{J}_{\boldsymbol{s c} \boldsymbol{\prime}}$ & $\boldsymbol{F F}$ & Eta \\
\cline { 2 - 5 } & $\mathbf{V}$ & $\mathbf{m A} / \mathbf{c m}^{\mathbf{2}}$ & $\mathbf{\%}$ & $\mathbf{\%}$ \\
\hline Initial & 0.797 & 35.51 & 68.25 & 19.33 \\
Optimized & 0.813 & 35.58 & 73.17 & 21.16 \\
\hline
\end{tabular}

We observed in Table 1 that, initially, the values of $V_{o c}, J_{S c}, F F$, and Eta were improved with optimized thickness and working temperature as shown in Table 1.

\section{Conclusions}

In this simulation study, we used a lead-free perovskite solar cell with model "Back Contact $/ \mathrm{CH}_{3} \mathrm{NH}_{3} \mathrm{SnBr}_{3} / \mathrm{CdS} / \mathrm{ZnO} /$ Front Contact". We increased the thickness of buffer layer from $1.0 \mu \mathrm{m}$ to $3.0 \mu \mathrm{m}$, and then efficiency increased from $16.17 \%$ to $20.81 \%$. Here, we also observed the effect of temperature. The temperature was increased from $290 \mathrm{~K}$ to $330 \mathrm{~K}$; hence, efficiency was reduced from $19.99 \%$ to $17.31 \%$. Considering both the optimization parameters, $\mathrm{CH}_{3} \mathrm{NH}_{3} \mathrm{SnBr}_{3}$ based perovskite solar cell exhibits the highest power conversion efficiency of $21.16 \%$ with the $V_{o c} 0.813 \mathrm{~V}, J_{\mathcal{~} C} 35.58 \mathrm{~mA} / \mathrm{cm}^{2}$, and FF $73.176 \%$. The creation of an ecofriendly methyl ammonium tin bromide perovskite solar cell is shown by these results. This increment in efficiency is very remarkable and will be very helpful for the researchers and the scientist to develop the lead-free perovskite solar cell on an experimental scale.

Institutional Review Board Statement: The study did not involve humans or animals.

Informed Consent Statement: Not applicable.

Data Availability Statement: Not applicable.

Acknowledgments: Author Muhammad Aamir Shafi acknowledge the Higher Education Commission of Pakistan, International Research Support Initiative Program (IRSIP) for grant No: 18/HEC/HRD/2020/10744 PIN: IRSIP 45 Engg 17. One of the Author Shafi Ullah acknowledged the post-doctoral contract supported by the, RRHH, postdoctoral contract (PAID-10-20), and Ministerio de Economía y Competitividad (Grant Number PID2019-107137RB-C21), Universitat Politécnica de València (UPV) Spain. Authors also acknowledge Marc Burgelman for providing the software SCAPS-1D.

Conflicts of Interest: The authors declare that they have no conflicts of interest. 


\section{References}

1. Kojima, A.; Teshima, K.; Shirai, Y.; Miyasaka, T. Organometal Halide Perovskites as Visible-Light Sensitizers for Photovoltaic Cells. J. Am. Chem. Soc. 2009, 131, 6050-6051. [CrossRef] [PubMed]

2. Green, M.A.; Ho-Baillie, A.; Snaith, H. The emergence of perovskite solar cells. Nat. Photonics 2014, 8, 506-514. [CrossRef]

3. Shin, S.S.; Yeom, E.J.; Yang, W.S.; Hur, S.; Kim, M.G.; Im, J.; Seo, J.; Noh, J.H.; Seok, S.I. Colloidally prepared La-doped BaSnO 3 electrodes for efficient, photostable perovskite solar cells. Science 2017, 356, 167-171. [CrossRef] [PubMed]

4. Burschka, J.; Pellet, N.; Moon, S.-J.; Humphry-Baker, R.; Gao, P.; Nazeeruddin, M.K.; Grätzel, M. Sequential deposition as a route to high-performance perovskite-sensitized solar cells. Nat. Cell Biol. 2013, 499, 316-319. [CrossRef] [PubMed]

5. Yang, W.S.; Park, B.-W.; Jung, E.H.; Jeon, N.J.; Kim, Y.C.; Lee, D.U.; Shin, S.S.; Seo, J.; Kim, E.K.; Noh, J.H.; et al. Iodide management in formamidinium-lead-halide-based perovskite layers for efficient solar cells. Science 2017, 356, 1376-1379. [CrossRef] [PubMed]

6. Miyata, A.; Mitioglu, A.; Plochocka, P.; Portugall, O.; Wang, J.T.-W.; Stranks, S.D.; Snaith, H.; Nicholas, R. Direct measurement of the exciton binding energy and effective masses for charge carriers in organic-inorganic tri-halide perovskites. Nat. Phys. 2015, 11, 582-587. [CrossRef]

7. Correa-Baena, J.-P.; Abate, A.; Saliba, M.; Tress, W.; Jacobsson, T.J.; Grätzel, M.; Hagfeldt, A. The rapid evolution of highly efficient perovskite solar cells. Energy Environ. Sci. 2017, 10, 710-727. [CrossRef]

8. Saliba, M.; Matsui, T.; Seo, J.-Y.; Domanski, K.; Correa-Baena, J.-P.; Nazeeruddin, M.K.; Zakeeruddin, S.M.; Tress, W.; Abate, A.; Hagfeldt, A.; et al. Cesium-containing triple cation perovskite solar cells: Improved stability, reproducibility and high efficiency. Energy Environ. Sci. 2016, 9, 1989-1997. [CrossRef]

9. Ono, L.K.; Juarez-Perez, E.J.; Qi, Y. Progress on Perovskite Materials and Solar Cells with Mixed Cations and Halide Anions. ACS Appl. Mater. Interfaces 2017, 9, 30197-30246. [CrossRef]

10. Zhang, T.; Meng, X.; Bai, Y.; Xiao, S.; Hu, C.; Yang, Y.; Chen, H.; Yang, S. Profiling the organic cation-dependent degradation of organolead halide perovskite solar cells. J. Mater. Chem. A 2017, 5, 1103-1111. [CrossRef]

11. Hussain, S.S.; Riaz, S.; Nowsherwan, G.A.; Jahangir, K.; Raza, A.; Iqbal, M.J.; Sadiq, I.; Naseem, S. Numerical Modeling and Optimization of Lead-Free Hybrid Double Perovskite Solar Cell by Using SCAPS-1D. J. Renew. Energy 2021, $2021,6668687$. [CrossRef]

12. Liu, F.; Zhu, J.; Wei, J.; Li, Y.; Lv, M.; Yang, S.; Zhang, B.; Yao, J.; Dai, S. Numerical simulation: Toward the design of high-efficiency planar perovskite solar cells. Appl. Phys. Lett. 2014, 104, 253508. [CrossRef]

13. Tan, K.; Lin, P.; Wang, G.; Liu, Y.; Xu, Z.; Lin, Y. Controllable design of solid-state perovskite solar cells by SCAPS device simulation. Solid-State Electron. 2016, 126, 75-80. [CrossRef]

14. Lin, L.; Jiang, L.; Qiu, Y.; Yu, Y. Modeling and analysis of HTM-free perovskite solar cells based on ZnO electron transport layer. Superlattices Microstruct. 2017, 104, 167-177. [CrossRef]

15. Shyma, A.P.; Sellappan, R. Computational Probing of Tin-Based Lead-Free Perovskite Solar Cells: Effects of Absorber Parameters and Various ETL Materials on Device Performance. 2021. Available online: https://www.researchsquare.com/article/rs-658718 /latest.pdf (accessed on 24 January 2022). [CrossRef]

16. Ball, J.M.; Stranks, S.D.; Hörantner, M.T.; Hüttner, S.; Zhang, W.; Crossland, E.J.W.; Ramirez, I.; Riede, M.; Johnston, M.B.; Friend, R.H.; et al. Optical properties and limiting photocurrent of thin-film perovskite solar cells. Energy Environ. Sci. 2015, 8, 602-609. [CrossRef]

17. Kischkat, J.; Peters, S.; Gruska, B.; Semtsiv, M.; Chashnikova, M.; Klinkmüller, M.; Fedosenko, O.; Machulik, S.; Aleksandrova, A.; Monastyrskyi, G.; et al. Mid-infrared optical properties of thin films of aluminum oxide, titanium dioxide, silicon dioxide, aluminum nitride, and silicon nitride. Appl. Opt. 2012, 51, 6789-6798. [CrossRef]

18. Filipič, M.; Loeper, P.; Niesen, B.; De Wolf, S.; Krč, J.; Ballif, C.; Topic, M. CH_3NH_3PbI_3 perovskite/silicon tandem solar cells: Characterization based optical simulations. Opt. Express 2015, 23, A263-A278. [CrossRef]

19. Hamakawa, Y.; Okamoto, H.; Nitta, Y. A new type of amorphous silicon photovoltaic cell generating more than 2.0 V. Appl. Phys. Lett. 1979, 35, 187-189. [CrossRef]

20. Moon, M.M.A.; Ali, M.H.; Rahman, M.F.; Hossain, J.; Ismail, A.B.M. Design and Simulation of FeSi2-Based Novel Heterojunction Solar Cells for Harnessing Visible and Near-Infrared Light. Phys. Status Solidi 2020, 217, 1900921. [CrossRef]

21. Hossain, S.; Amin, N.; Martin, M.A.; Aliyu, M.M.; Razykov, T.; Sopian, K. A numerical study on the prospects of high efficiency ultra thin $\mathrm{Zn}_{\mathrm{x}} \mathrm{Cd}_{1-\mathrm{x}} \mathrm{S} / \mathrm{CdTe}$ solar cell. Chalcogenide Lett. 2011, 8, 263-272.

22. Sha, W.E.I.; Ren, X.; Chen, L.; Choy, W.C.H. The efficiency limit of CH3NH3PbI3 perovskite solar cells. Appl. Phys. Lett. 2015, 106, 221104. [CrossRef]

23. Shafi, M.A.; Khan, L.; Ullah, S.; Shafi, M.Y.; Bouich, A.; Ullah, H.; Mari, B. Novel Compositional Engineering for 26\% Efficient CZTS-Perovskite Tandem Solar Cell. Optik 2022, 253, 168568. [CrossRef] 